\title{
Venezuela: Deeper into the Abyss
}

\author{
Venezuela: a las puertas del abismo
}

\section{JULIA BUXTON}

Central European University, Hungary

\begin{abstract}
Fissures between the ruling Partido Socialista Unido de Venezuela (PSUV) and its grassroots base widened amid disaffection with the dismal economic performance of President Nicolás Maduro's government and the trend of militarization in his administration. Economic crisis and chronic insecurity accelerated migration. Opposition strategies of violent protest resumed as the executive continued to bypass the opposition-controlled legislature. Long-term divisions within the Mesa de la Unidad Democrática (MUD) alliance over strategies for removing the government prevented the opposition from capitalizing on social discontent. The rift between parties supporting electoral approaches and more radical perspectives pressing for the overthrow of the government were replicated among external actors, whose interventions aggravated rather than alleviated political tensions.
\end{abstract}

Keywords: conflict, dialogue, economic crisis, National Constituent Assembly

\section{RESUMEN}

En el contexto de pobre desempeño económico del gobierno del presidente Nicolás Maduro y de la militarización de su administración, las fisuras entre el oficialista Partido Socialista Unido de Venezuela (PSUV) y su base electoral se ampliaron. La crisis económica y la inseguridad crónica aceleraron la migración. La oposición reanudó las estrategias de protesta violenta como respuesta a un poder ejecutivo que continuó desestimando a una legislatura controlada por la oposición. Las divisiones dentro de la alianza de la Mesa de la Unidad Democrática (MUD) sobre las estrategias para remover al gobierno evitaron que la oposición aprovechara el escenario de descontento social. La brecha entre los partidos que apoyan el camino electoral y aquellos actores con propuestas más radicales que presionan para el derrocamiento del gobierno se replicó entre actores externos, cuyas intervenciones terminaron por agravar las tensiones politicas en vez de aliviarlas.

Palabras clave: conflicto, diálogo, crisis económica, Asamblea Nacional Constituyente 


\section{INTRODUCTION}

This assessment of developments in 2017 maintains the pessimistic tone of previous yearly reviews for RCP (Cyr 2013; Cannon and Brown 2017), underpinned by frustration at the inability of Venezuela's elites, regional bodies, and the international community to reverse the country's descent into ever-deeper economic and political chaos. While there may be a plethora of hemispheric and global conventions on the protection of democracy and human rights, and an accumulation of lessons learned on conflict prevention and reduction, the paralysis on the "Venezuela issue" is a case study of the gap between lofty principles and their actual upholding.

Approaching the twentieth anniversary of late President Hugo Chávez's election in December 1998 and the launching of the Bolivarian Revolution (Gott 2011), political rhetoric, calculations, and strategies in the country have remained polarized and "frozen," with the government and its opponents incapable of moderation or reconciliation. Venezuela's political crisis has played out as a battle, with the government and Mesa de la Unidad Democrática (MUD) variously marshalling, advancing, and retreating. With this dynamic unchanged, 2017 was a rerun of previous years: a nihilistic "business as usual" with ever worsening cumulative impacts on Venezuela's economy, oil industry, and infrastructure. The survival of the government through a perilous year of protests, international isolation, and economic implosion can be attributed to factors that include electoral and constitutional manipulation, coercive repression by state forces, divisions within the perennially factionalized MUD, and the ongoing, if diminished, popularity of the Bolivarian Revolution.

\section{ECONOMY AND SOCIETY}

When Hugo Chávez was elected to the Venezuelan presidency in 1998, he displaced a dominant two party system that had governed the country since democratization in 1958 (McCoy and Myers 2006). His Bolivarian Revolution was committed to overturning Puntofijismo, a model of institutionalized two party control of the state, institutions, and political organization (Ellner and Tinker Salas 2006). The Bolivarian Revolution promised participatory democracy, a Third Way economic model, and a meritocratic state (López Maya and Lander 2010). Over the course of fifteen years in power until his death in March 2013, Chávez veered away from initially modest ambitions on poverty reduction, social inclusion, and institutional reform. His third presidential term (2006-2012) marked a shift to "Socialism of the Twenty First Century" and the telescoping of the Revolution's ambitions of restructuring economic and political relations (Álvarez 2007: 267; López Maya and Lander 2010: 538).

This section discusses the deepening of Venezuela's economic crisis in 2017. The examples of public health and security are used to elaborate the mismanagement 
and deterioration experienced under the Maduro government-with a new nadir reached in 2017-and to highlight the complex legacy of oil dependence, state overextension, and institutional politicization that Maduro inherited. According to bodies including the UN, OAS, and the US Congress, the situation in Venezuela constituted a "humanitarian crisis," prompting an exodus from the country that accelerated in 2017, with tens of thousands of Venezuelans fleeing to neighbouring Brazil (Human Rights Watch 2017a), Colombia, and on to third country destinations (Woody 2017). As discussed below, chronic deterioration of the economy and security situation were drivers of this migration.

Chávez jettisoned a commitment to diversify the national economic base and reduce dependence on oil exports, which accounted for approximately 95\% of export earnings, $60 \%$ of budget revenues, and 12\% of GDP (Monaldi 2015). During his third term (2006-2012), Chávez declared the oil sector the "motor of the revolution," reorienting Venezuela back to an inglorious economic history of boom and bust economic cycles (Di John 2009) as new supplies, such as US shale, were coming into global energy markets.

After peaks of over $\$ 100$ per barrel (p/b) early in Chávez's third term (20062008), oil prices began a perilous descent that accelerated after Maduro took office. Dipping to an average of $\$ 44 \mathrm{p} / \mathrm{b}$ in 2015 , the oil price maintained a downward trend in 2016 to $\$ 35 \mathrm{p} / \mathrm{b}$. Venezuela engaged in diplomatic efforts to encourage OPEC and non-OPEC countries such as Russia to reduce oil production in an effort to lift prices. Effective as of 1 January 2017, OPEC countries reduced production by 1.2 million barrels per day $(\mathrm{mb} / \mathrm{d})$ for a six month period, with Venezuela negotiating a $2.17 \mathrm{mb} / \mathrm{d}$ to $1.97 \mathrm{mb} / \mathrm{d}$ national reduction. The cuts were extended for a further nine months in July, and in November oil producers agreed to maintain reductions of $1.8 \mathrm{mb} / \mathrm{d}$ until the end of 2018 (Lawler, El Gamal and Nasralla 2017).

By the end of 2017, Venezuelan crude had not recovered to the $\$ 60 \mathrm{p} / \mathrm{b}$ ambitions outlined at the beginning of the year by Maduro, intensifying fiscal pressures on the Venezuelan treasury and accelerating the depletion of dollar earnings. The international reserve position weakened dramatically. In June 2017, reserves fell below $\$ 10$ billion for the first time in 15 years, decreasing 77\% from a January 2009 peak of $\$ 43$ billion. An estimated 70\% of Venezuelan Central Bank reserves were in gold, which experienced a 14\% decline in value in 2017 (Reuters 2018, 15 March). There was intense speculation Venezuela would default on re-payment of sovereign and PDVSA debt totaling \$2.2 billion due in April 2017 and \$4.9 billion repayments between September and December 2017.

The squeezing of imports to save dollars for debt repayment exacerbated an acute shortage of basic and medical goods. Venezuela fulfilled its April debt obligations but on 2 November Maduro announced Venezuela could not meet the latter tranche of repayments. With a further \$9 billion due in 2018, Maduro acknowledged that Venezuela would need to restructure its debt. This led to two downgrades on Venezuela's ratings to $C$ and CC by Fitch and Standard \& 
Poor's on 3 November. There was little confidence in Venezuela's capacity to renegotiate outstanding obligations due to the limited technical capacity of the national finance team and following an 25 August order by US President Donald Trump prohibiting US institutions from trading in financial instruments issued by the Venezuelan government or PDVSA. Amid intense credit constraints, Maduro announced on 2 December a digital currency to overcome international financing obstacles. The 'petro' was to be backed by oil, diamond, gold and gas reserves but given the government's financial opacity and poor record on monetary policy, did not generate significant investor interest.

Oil production remained on a downward trend owing to legacies of underinvestment, corruption and politicization at PDVSA, which the Chávez government had overhauled and reoriented to the service of the Revolution (Tinker Salas 2009; Hellinger 2016). The Chávez administration had initially planned to double oil output to six million b/d but by 2017 , oil output was estimated at $1.9 \mathrm{~m} \mathrm{~b} / \mathrm{d}$, with capacity loss of $221,000 \mathrm{~b} / \mathrm{d}$ in the first half of the year. This made oil based repayments of 750,000 b/d on debts to China and Russia onerous. An additional 50,000 b/d was ring-fenced for commitments under oil exchange programs, particularly with Cuba. The retention of a regressive subsidy on domestic gasoline fed an additional 400,000 b/d to the local market at a loss (Monaldi 2018, 24 January).

Dollar shortages were not alleviated by the government's exchange rate controls, which prioritized access to dollars for essential imports at a rate of 10:1 (bolivares to dollar) and 3,345:1 for other goods. The system, initially introduced in 2003 to prevent capital flight after a coup attempt against Chávez in 2002, was a driver of graft and corruption (Dachevsky and Kornblihtt 2016). The politically connected benefited from access to discounted rates, while the black market reached highs of 103,000:1 at the end of 2017. Price controls that had also been introduced in 2003 remained in effect, fueling inflation and exacerbating shortages (Weisbrot 2016, 23 October). Venezuela entered into a hyperinflationary spiral from November 2016 when monthly inflation surpassed 50\% (Hanke 2018, 25 April). Annual inflation for 2017 was estimated at $2,616 \%$, the highest in the world, with December inflation recorded at $85 \%$ (Reuters 2018).

\section{PUBLIC HEALTH AND SECURITY CRISIS}

Social policy initiatives were a centrepiece of Chávez's early tenure and the foundation of the Revolution's ambitions of building a fairer and more inclusive society in a country characterized by searing inequalities. The government's approach typically followed international best practice (Spanakos and Pantoulas 2017) and by 2010 the government reported significant progress in reaching Millennium Development Goal targets (Valero 2010). This was enabled by an increase in the proportion of GDP dedicated to social spending, made 
possible by high oil export prices after 2004, and the government's capture of a greater share of oil export revenues from the national oil company Petróleos de Venezuela, S.A. (PDVSA).

Improving access to health care had been a priority for the Chávez administration (Buxton 2017a). The government's approach was informed by the social medicine philosophy that emphasised health as a human right, as championed by health ministers Gilberto Rodríguez Ochoa (1999) and Maria Lourdes Urbaneja (2001). As oil revenues began an upward trend after 2003, the Barrio Adentro program (into the neighbourhood) rolled out in situ curative and preventative health care through integrated medical centres. Through to the Barrio Adentro 3 initiative, launched in 2007, health care evolved to the construction of specialist hospitals and community clinics covering $68 \%$ of the population and free treatment of HIV and cancer. Chávez's third term (2006-12) squandered opportunities to consolidate these gains. Innovative policies were poorly followed through in practice and the government failed to develop non-oil revenue funding streams. Lacking national consultation in design and implementation, social policies lacked oversight or national consensus, in turn making them vulnerable to roll back from the MUD-dominated National Assembly in 2016 and 2017 (Cannon and Brown 2017, 614).

On 9 May 2017, official health data from 2016 was released. This showed an annual $30 \%$ and $65 \%$ increase in infant and maternal mortality respectively, and a sharp rise in incidents of preventable diseases including diphtheria, dengue, pneumonia, HIV, measles, and Zika. Incidences of malaria rose by $76 \%$ yearover-year to nearly 250,000. Infant mortality claimed 11,500 lives in 2016, while maternal mortality totalled 756 cases. According to UNICEF's regional office: "data on infant and maternal deaths [...] in Venezuela provides stark evidence of the impact of the prolonged crisis on women and children in the country" (UNICEF 2017). 85\% of medicines were unavailable and acute shortages of medical supplies, surgical materials, water, sanitary products, and disinfectant was reported. Operating theatres and processing labs were running at an estimated $20 \%$ of capacity and an estimated 13,000 doctors had left the country (Dickinson 2016).

The minimum wage, measured in cheapest available calories, collapsed from 52,854 calories per day in May 2012 to 2,740 calories a day at the end of 2017. ENCOVI reported that $30 \%$ of the population was eating less than two meals a day, as the national poverty reached 82\% in 2017 (Hausmann 2018, 2 January). Throughout 2017 the government resisted NGO and MUD demands for a "humanitarian corridor" for medical supplies and food to be brought into the country. Seeing this as a Trojan horse for an externally led intervention against Maduro, the government addressed rising problems of stunting and malnutrition through state distribution of food through Comités Locales de Abastecimiento y Producción (CLAPS). Introduced in March 2016, these connected grassroots community groups to state distribution networks (Cannon and Brown 2017, 620). On 1 March 2017, Maduro announced plans to extend the anti-scarcity 
initiative by an additional 250,000 households to achieve distribution to 6 million families.

As the centrepiece of the government's response to "economic warfare" by the US and domestic elites, CLAPS were inadequate and contested. The initiative politicized access to food, with evidence of supply and distribution concentrated in areas loyal to the government. Representatives from Chavista organisations complained of being bypassed in the CLAP initiative and there was frustration that local and small-scale producers were marginalized, with the government distributing goods from large private sector manufacturers. The CLAP boxes, priced at 8,200 bolivars, were criticised as an opportunity for corruption and illicit enrichment through the official and black market exchange rates (Martin 2018).

Social and state violence were ongoing problems (Sánchez Urribarrí 2016, 369), with Venezuela ranking in the top five countries of the world for violent homicide (Small Arms Survey 2017). On 31 March 2017, the Attorney General's office acknowledged the official homicide rate as 21,752 murders in 2016, or 60 violent deaths per day (Gagne 2017), an increase from the 45 per day officially recorded in 2015 and elevating the murder rate to 70.1 per 100,000, in contrast to the 20 per 100,000 in 1998 when Chávez first won power (Maingon and Welsch 2009, 635). The Observatorio de Violencia reported 28,479 violent deaths in 2016, which included those killed in clashes with the security sector. For 2017, the Observatory calculated 26,616 victims of violent death, including 15 people per day killed by the police or military (Merco Press 2017).

Venezuela had a long-standing problem with homicide that the incoming Chávez administration pledged to address. No progress was achieved due to a persistent turnover of officials in the Ministry of Interior and Justice that prevented the consolidation of multiple disarmament, police reform, and citizen security programs. There was chronic underinvestment in the criminal justice system, an estimated 6 million illegal firearms were in circulation despite a 2012 ban on private gun ownership, and the underperformance of forensic policing meant only $8 \%$ of homicides were effectively investigated.

Those most likely to be the victims of homicide were young men, but violence against women came into sharp relief in 2017 with the murder of feminist activist Sheila Siva on 22 October. A victim of intimate partner violence, the death of Siva focused attention on the mismatch between the rhetoric of the Bolivarian Revolution and policy delivery. In March 2007, the Chávez government had introduced the Organic Law on the Right of Women to a Life Free of Violence, which defined 19 types of violence against women as human rights crimes. This responded to an "epidemic" of domestic violence, with a woman assaulted by an intimate male partner every fifteen minutes (Amnesty International 2008). In 2017 the Maduro government attempted to re-establish the gender-sensitive credentials of the Bolivarian Revolution. The Soy Mujer program of April saw a relaunch of the dedicated women's bank Banmujer (Ladera 2017) and a new 
anti-domestic violence initiative, "Peace Begins at Home: No More Violence against Women." Anti-violence campaigners highlighted the lack of legal, social, and economic support for complainants, poorly resourced and unsympathetic policing, and politically related impunity as the drivers of ongoing violence (Zuñiga 2018).

Political conflict focused debate and activism around meta-issues of regime legitimacy. This forced a number of social issues off the political agenda, including reproductive and LGBT rights. Neither the Chávez nor the Maduro administrations addressed Venezuela's strict abortion laws, with mortality related to illegal abortion a leading cause of death for Venezuelan women and girls (Barbarani 2016). On 28 September, feminist groups mobilized around sexual, reproductive, and identity rights, issues that also remained off the MUD agenda (Kozarek 2017).

\section{POLITICAL CONTEXT}

The year started inauspiciously, with the breakdown of dialogue efforts and the resumption of anti-government protests that persisted throughout the year. On 19 January 2017, the Vatican withdrew its envoy from a dialogue initiative between the government and MUD launched October 2016 with the backing of the outgoing Obama administration. Key sticking points that prompted opposition parties to boycott a third meeting scheduled for 13 January 2017 included the provision of a humanitarian corridor, the release of political prisoners-in particular, the Voluntad Popular (VP) leader Leopoldo Lópezand personnel changes in state institutions. For the government, the MUD's twin strategy of mobilizing protests alongside the dialogue process was a point of contention.

Prospects for dialogue were bleak amid ongoing political and constitutional conflict between the government and the MUD-controlled National Assembly. On 9 January, days before the talks were to resume, the National Assembly found Maduro responsible for a breach of the constitutional and democratic order, human rights violations, and devastation of the economy. The National Assembly's declaration that Maduro had abandoned office prompted the government to declare the National Assembly "self-dissolved" for overstepping its constitutional role. The arrest of a number of opposition politicians on terrorism charges followed on 11 and 12 January (Amnesty International 2017). The MUD reconvened mass national protests on 23 January. This was despite previous protests, most particularly in February 2014, failing to dislodge the government while exacting a heavy toll in violence and destruction of property. The April 2014 protests had seen 43 deaths and the arrest of VP's Leopoldo López, who was sentenced in 2015 to 13 years and 9 months for inciting the violence. On 16 February 2017 the TSJ upheld the sentence, galvanizing renewed MUD protests. 
Political developments in 2017 were framed by two decisions that were taken in 2016 by the Tribunal Supremo de Justicia (TSJ) and the Consejo Nacional Electoral (CNE), and which Vatican-led talks failed to resolve. In January 2016 the TSJ had declared the National Assembly "void" after three opposition deputies under investigation for electoral malpractice were sworn in. This created a situation of constitutional limbo, with the TSJ overturning National Assembly legislative initiatives throughout 2016 and 2017 (Cannon and Brown 2017, 616). The TSJ staged a clumsy intervention on 29 March 2017 when it usurped the functions of the National Assembly to rule on the legality of a joint venture in the hydrocarbons sector. The move was legitimized through Article 336.9 of the 1999 Constitution, which empowered the Court "to resolve constitutional controversies arising between any of the organs of Public Power." The decision was reversed on 1 April after condemnation by the US, the Vatican, and the Permanent Council of the OAS. In a rare show of dissent within the PSUV, Attorney General Luisa Ortega Díaz supported the National Assembly's authority. Following the usual trajectory of Venezuela's political conflict, the opposition sought to capitalise on the TSJ retreat and went ahead with a national protest on 4 April. The new round of anti-government demonstrations took a bloody toll. Within the first three weeks of looting and protests, including "the mother of all protests" on 19 April, 24 people were killed.

The decision by the CNE in October 2016 to reject a recall referendum on Maduro, and to delay into 2017 state governor elections scheduled for December 2016 (Cannon and Brown 2017) undermined the national and international credibility of the CNE, which had made strides in improving Venezuela's electoral processes in the early 2000s. Absent opportunities for political change through the ballot box, the CNE's actions elevated the role of the street as the main forum for articulating grievance.

On 1 May 2017, Maduro decreed a National Constituent Assembly (NCA). This came a matter of days after Venezuela announced that it would be withdrawing from the OAS. Maduro presented the NCA as a mechanism for conflict resolution but the constitutionality of the initiative was rejected by the National Assembly. The MUD boycotted the NCA election that was held on 30 July 2017 and refused to accept the legitimacy of the new body, which Maduro declared sovereign when it convened on 4 August 2017. The US, Canada, Argentina, and Mexico were among those countries that refused to recognise the NCA, which was seen as a government mechanism to bypass the National Assembly. One of the first acts of the NCA was to dismiss Attorney General Luisa Ortega and move forward the delayed state governor elections from December to October 2017.

Smartmatic, the firm responsible for Venezuela's voting software, publicized its concerns that the official participation rate of 8.1 million voters in the NCA elections was manipulated. Only 3.7 million people had voted by 5:30 PM, thirty minutes before polls closed (Gupta 2017). By contrast, an estimated 7.4 million Venezuelans participated in an informal three-question consultation convened by the National Assembly held on 16 July 2017. Over 99\% rejected the 
convening of the NCA, supported the demand that the Armed Forces uphold the 1999 constitution, and approved the renewal of public powers.

In line with Cannon and Brown's $(2017,623)$ argument that the Venezuelan opposition movement shares responsibility for the intractable nature of the country's political crisis, 2017 saw the MUD continue to be undermined as an effective alliance by internal disputes. Rather than focusing on the drafting of a consensual post-Chavista policy program, and listening to and articulating popular concerns, the MUD prioritized mobilizing external opinion (Buxton 2017b). The MUD lobbied the US, OAS, and EU around demands including immediate elections, the release of political prisoners, and for sanctions against officials, but without presenting a coherent alternative plan of government. Perennial divisions over strategy continued to pit more moderate elements grouped around the Primero Justicia (PJ), Acción Democrática (AD), Avanzada Progresista (AP) and Un Nuevo Tiempo (UNT) parties that saw elections as a mechanism for political change, against more intransigent elements grouped in López's VP, Maria Corina Machado's Vente Venezuela (VV) and Antonio Ledezma's Alianza Bravo Pueblo (ABP) that advocated for protests and abstention from elections and dialogue efforts (Velasco 2018). For the first half of 2017, an uneasy modus vivendi ensued that saw the opposition pursue a combination of protest, international lobbying, and boycott of the NCA.

Divisions re-emerged over participation in the 15 October 2017 state governor elections, which saw a strong performance by the ruling PSUV amid MUD disputes and half-hearted campaigning. The MUD won five governorships (four by AD candidates) and received $45.1 \%$ of votes against $52.7 \%$ for the PSUV. Schisms deepened when the AD governors accepted to be sworn in by the NCA, violating the MUD agreement not to recognize the body. On 24 October, PJ leader Henrique Capriles announced he was leaving the MUD despite AD's expulsion of the four governors. PJ, AD, ABP and VP were among a number of opposition parties that boycotted municipal elections held on 10 December.

Despite the bellicose rhetoric between the government and its opponents (Latouche 2016), dialogue remained an option, with a new round of talks convened in the Dominican Republic on 13 September. These were led by former Spanish Prime Minister José Luis Rodríguez Zapatero and Danilo Medina, president of the Dominican Republic, with the support of the EU, the Vatican, and the UN General Secretary. This followed the creation of a six-country group of friends to support dialogue efforts. Maduro matched influential MUD representatives at the talks (including the National Assembly President Julio Borges) with the mayor of Libertador, Jorge Rodríguez, NCA President and former foreign minister Delcy Rodríguez and diplomat Roy Chaderton.

The talks floundered amid ongoing disagreement over MUD preliminary conditions for participation. On 16 November the MUD sent a delegation to the Dominican Republic to prepare for new talks on 1 and 2 December. With no consensus achieved on a six-point agenda, the parties reconvened on 15 
December and made "significant progress," according to Medina, in an eight hour meeting, with a commitment to reconvene in the Dominican Republic on 11 January 2018 (Ramsey 2017). Despite the end-of-year optimism, the MUD delegation had no capacity to bind more radical opposition factions to any agreement, and their participation in the talks continued to be bitterly contested by the VP, VV, and ABP parties.

\section{INTERNATIONAL DIMENSIONS}

Donald Trump assumed the US presidency in January 2017 with US-Venezuelan bilateral ties at an all-time low. In 2014, Senators Marco Rubio and Robert Menendez spearheaded the Venezuela Defense of Human Rights and Civil Society Act that froze the assets and barred travel to the US of Venezuelan officials implicated in human rights abuses. The measure came into effect through a 2015 Executive Order of President Obama (White House Press Secretary 2015) and sanctions against seven Venezuelan officials including the directors of the national intelligence service, police, and a national prosecutor followed. In July 2016, Obama signed an extension of the 2014 legislation.

The Trump administration retained the sanctions approach, and in February named Venezuelan Vice-President Tareck el Aissami as a Specially Designated Narcotics Trafficker pursuant to the Foreign Narcotics Kingpin Designation Act (Kingpin Act) (US Department of the Treasury 2017). US sanctions against a further 42 officials followed in 2017, including 8 TSJ officials in May 2017, the president of the CNE in July 2017, and against Maduro on 31 July 2017 following the NCA election. Maduro was one of only four heads of state to face a US travel ban and asset freeze. There were two further rounds of sanctions in September 2017.

The US encouraged other countries to adopt the sanctions regime, and Canada followed on 22 September 2017, with 56 officials targeted in two rounds. The effectiveness of the sanctions regime was questionable (Ramsay 2017; Smilde 2017). There was no discernible impact on government policy or political calculations, and the sanctions appeared to bind officials to the Maduro government rather than encourage dissent. A number of South American countries supported the sanctions, but none followed through with their own national initiative, and the coordination of the remit and targets of the sanctions was poor.

The Trump administration jettisoned multilateral approaches to Venezuela on two salient occasions. On 11 August 2017 Trump mulled "a possible military option if necessary" (New York Times 2017), an echo of Admiral Kurt Tidd, Commander of the US Southern Command (United States Southern Command 2017). On 25 August, US Treasury sanctions were extended from individual Venezuelan officials to the financial sector. This derailed Venezuela's options for restructuring its debt as the onerous repayment schedule of October to 
November 2017 loomed. South American countries distanced themselves from the threat of a military intervention, which, like the financial sanctions, risked aggravating social suffering and strengthening nationalist sympathy for Maduro (Rodríguez 2018).

On 16 February 2017, Trump met with Lilian Tintori, the wife of Leopoldo López. The US president tweeted a photograph of the meeting and a caption demanding the release of political prisoners. This was a powerful message of US backing for the abstention factions of the MUD. On 17 February, the Venezuelan TSJ rejected López's appeal against his prison sentence. On 8 July he was allowed to leave the Ramo Verde military prison for house arrest. The TSJ decision did not pacify international criticism or opposition protests. On 1 August, the day after the NCA election, the house arrest of López and ABP leader Antonio Ledezma was rescinded. The TSJ also ordered the arrest of five opposition mayors who were charged with failing to remove protest barricades in their municipalities. Ledezma fled to Colombia on 16 November 2017.

The OAS demonstrated negligible capacity to contain Venezuela's crisis despite the increasingly severe impact of the country's deterioration on neighboring states. OAS General Secretary Luis Almagro maintained incautiously close relations with senior MUD figures. On 14 March Almagro called for the OAS Democratic Charter to be invoked against Venezuela, but in the absence of diplomatic overtures to states sympathetic to Venezuela including Bolivia, Ecuador, and Nicaragua, Almagro failed to achieve necessary OAS consensus. At the OAS General Assembly meeting on 20 June in Cancun, Mexico, Almagro failed to secure a motion critical of Venezuela.

On 27 April 2017, Venezuela announced its intention to leave the OAS. As with Mercosur's decision on 5 August 2017 to suspend Venezuela, the country's withdrawal, forced or voluntary, from regional bodies reduced channels for diplomacy. During the 2000s, Chávez was pro-active in establishing a new architecture of regional organization, informed by his hostility to the OAS (Cusack 2018). But neither UNASUR (established in 2008) nor the Community of Latin American and Caribbean States (CELAC established in 2011) assumed effective roles in negotiating Venezuela's political crisis. At a 2 May 2017 CELAC meeting called by Venezuela, countries failed to reach consensus on the "Venezuela issue" and Maduro did not receive official CELAC endorsement (EFE 2017).

With South and Central American countries unable to establish a common position, the diplomatic interventions of those states that assumed a critical stance were clumsy and ineffective. Argentina, Peru, Mexico, and Brazil worked with Canada in the 12-country Lima Group established on 8 August 2017. The Lima Declaration (Ministerios de Relaciones Exteriores 2017) condemned human rights abuses in Venezuela and reiterated MUD demands for the release of political prisoners, renewal of electoral authorities and recognition of the National Assembly. Therse were followed by Group meetings in New 
York in September and Toronto in October, but in a pressing situation of humanitarian crisis the Group made no progress in its objective of exploring "ways to contribute to the restoration of democracy [...] through a peaceful and negotiated solution." It was unclear how the Lima Group could be effective; its meetings were infrequent, there was no mechanisms for monitoring the impact of sanctions, and the Group failed to reach out to countries sympathetic to Venezuela and whose support was vital for a realistic possibility of deescalating the country's crisis, including Bolivia and Ecuador at the regional level and Russia and China internationally.

Russia and China were an important counter to the US, OAS, and EU. Both countries maintained a position of non-interference in the sovereign affairs of nation states. After a loan of $\$ 2.2$ billion to Venezuela in November 2016 China extended modest further credits despite Venezuela falling behind on shipments of an estimated 9 million barrels of oil in repayment for lending from China that was estimated to total $\$ 65$ billion (Chun 2017). China allowed a debt repayment moratorium until January 2018, but ceased incremental lending in the second half of 2017. US financial sanctions and a reduction in lending from China increased Venezuela's reliance on Russia.

There were significant benefits to Russia of deepening ties in 2017. In the long term, investment in Venezuela's oil sector positioned Russia to extend its energy footprint in the Americas, but more immediately it enabled the Russian state oil company Rosneft to sustain oil production at a time when US sanctions on Russia were impacting Western technical support and partnerships. On 23 December 2016, Rosneft announced a $\$ 6$ billion loan to PDVSA to be repaid in oil shipments and underwritten by a $49.9 \%$ share in Citgo, PDVSA's US based subsidiary (Curacao Chronicle 2016). This opened the prospect of a Russian state-controlled company taking control of a major US domestic refiner and retailer. In October 2017, Russian finance minister Anton Siluanov announced a restructuring of $\$ 3.15$ billion of sovereign debt repayments to enable Venezuela to meet other creditor obligations.

\section{ELECTIONS}

Three national elections were convened in 2017 in conditions that did not qualify as free and fair: the National Constituent Assembly on 30 July, state governor elections on 15 October, and municipal elections on 10 December. On 1 May, Maduro announced the use of presidential privilege under article 347 of the 1999 Constitution to convene a National Constituent Assembly. Approximately two-thirds of Assembly's 535 members were elected in municipalities, with 79 candidates chosen from labour organisations, 28 from retirees, 24 from communal councils, 24 reserved for students, and 8 seats for representatives from rural workers and the fishing industry. The disabled and the business sector were allocated 5 representatives each. Amid opposition mobilization 
against the NCA, one candidate was murdered on the eve of the election, election-day was marred by a bomb attack on a police motorcycle convoy that injured seven officers, and ten people were killed in protests.

The October regional governor contest was preceded by a reallocation of 270 of the country's 13,599 voting centres premised on security concerns. This impacted 700,000 voters. Regional ballot papers contained the names of ineligible opposition candidates who had been defeated in MUD's internal primaries and for the first time, and election ink was not used to mark the fingers of people who had voted. Among the grassroots base of the Grand Patriotic Pole of minor left wing parties grouped around the PSUV, there was disaffection with candidate selection procedures. Senior government and military officials were parachuted into regional candidacies to the detriment of local leaders. Official figures demonstrated high turnout for a regional election, at $61 \%$, up from $53 \%$ in the 2012 state governor elections (Sagarzazu 2014) but below the $74.2 \%$ in the December 2015 National Assembly elections that generated an MUD landslide.

The PSUV captured 18 of the 23 state governorships with an increase in its share of the vote relative to the 2012 and 2015 election contests. Despite the pressing economic situation, the party continued to command the loyalty of a sizeable sector of the electorate, attributed to distrust of the MUD, loyalty to the memory of Chávez, and PSUV targeting of its base with government programs (Velasco 2017). A key gain was the populous capital region of Miranda, long the stronghold of PJ's Henrique Capriles. The MUD won 5 states: Anzoátegui, Mérida, Nueva Esparta, Táchira , and Zulia, up from three in 2012. The national tally of votes demonstrated a stronger MUD performance than was reflected in the capture of just 5 states. While the GPP received 5,817,344 votes, $4,984,830$ voters backed MUD candidates, up from 3,883,037 in 2012. There was controversy in the industrial state of Bolívar, where $0.3 \%$ separated the defeated MUD candidate Andrés Velásquez from the PSUV's Justo Noguera. In Zulia the regional election was rerun when PJ's Juan Guanipa refused to be sworn in by the NCA, with the PSUV candidate Omar Prieto taking the governorship with $57 \%$ of the vote in the rescheduled December contest.

The MUD disputed the CNE results, but this made the opposition vulnerable to the counter claim that they accepted the CNE's election results when they triumphed (as in December 2015) but not when defeated. The opposition failed to back up claims of fraud with evidence. MUD campaigning lacked any positive messaging or plans for regional government, and amid confusing MUD signals over their participation, there was an increase in abstention in its regional strongholds. The accuracy of the official CNE results for the October election was upheld by the Latin American Council of Electoral Experts, which provided 1,300 international observers to the October election.

Municipal elections that had been delayed from 2016 were held on 10 December 2017. At the end of October, the AD, PJ, VP and other, smaller organizations in the MUD announced a boycott. Henri Falcon, previously a Chávez ally, former 
governor of Lara state and leader of the $\mathrm{AP}$, supported participation, as did the UNT and Movimiento al Socialismo (MAS), with the parties offering space on their tickets to candidates from the boycotting parties. Voter participation in the December contest fell back after the strong turnout in October and was 10\% lower than the 2013 municipal elections, with official figures citing $47.3 \%$ participation. With the partial opposition boycott, the electoral space was conceded to the PSUV, which won 308 of the country's 335 mayoral seats, including in Caracas. The opposition took only two regional capitals, San Cristóbal in Táchira and Libertador in Mérida state, both victories for the Christian Democrat (COPEI) party. As with the October regional elections, the selection of PSUV mayoral candidates opened up divisions between communal organizations and the party hierarchy, with independent Chavistas challenging the PSUV nomination in a number of municipalities (Mallett Outtrim and Koerner 2017).

\section{EXECUTIVE POWER}

Figures previously close to Chávez were marginalized from circles of influence during the course of the year, and the military gained an increasingly influential role in government (Smilde 2016). While Chavismo had originally been intended as a joint civil and military project, by 2017 the balance had swung away from community organizations and sectoral groups that were the original heart of the Bolivarian Revolution.

In August 2017, the government launched a corruption investigation at PDVSA and CITGO. This focused on Rafael Ramírez, the former minister of oil and head of PDVSA (2002-2014) and responded to allegations of money laundering and contract irregularities under investigation by Swiss and US authorities. In February 2016 the National Assembly had announced its own investigation into Ramírez for alleged administrative irregularities amounting to $\$ 7$ billion. Nevertheless, the government's corruption drive was seen to be politically motivated. Ramírez issued a searing critique of the Maduro presidency and swore loyalty to the legacy of Hugo Chávez (Ulmer 2017).

The portfolio of Eulogio del Pino, who succeeded Ramírez in the posts of oil minister and president of state oil company PDVSA, was divided in a 24 January 2017 cabinet reshuffle. Nelson Martínez the former head of the CITGO refining arm was appointed oil minister. Martínez temporarily assumed the head of PDVSA, before Del Pino returned as oil minister in August. On 3 December, the separation of PDVSA and the ministry was again reversed, with both men replaced by Major General Manuel Quevedo who had no previous experience of the oil industry. Del Pino and Martínez were arrested in the government's PDVSA corruption investigation, which saw more than 60 senior and mid-level PDVSA and CITGO employees detained. Both men denied the charges, and their replacement by Quevedo heightened concerns of military influence in strategic industries. 
Maduro was heavily reliant on the armed forces for the staffing of his government in 2017. The 24 January cabinet reshuffle saw Admiral Carmen Meléndez become vice-president of political sovereignty, security, and peace. Colonel Ramón Velásquez was made minister of eco-socialism and water, and Admiral César Salazar Coll was appointed Minister of Public Works. Vladimir Padrino López and Néstor Reverol retained their posts as minister of defence and interior, respectively. Maduro's dependence on the military created favourable conditions for security sector impunity and rent-seeking opportunities. Human rights organisations highlighted security sector abuses that included arbitrary detention, torture, maltreatment of detainees, forced evictions, extrajudicial killings, and the use of military courts to prosecute civilian protestors (Amnesty International 2017; Human Rights Watch 2017b). The military resisted National Assembly calls for an intervention against Maduro. Despite speculation as to discontent in junior ranks, the command system of the Bolivarian armed forces withstood small scale rebellions including a helicopter attack on the TSJ in Caracas on 27 June and in Valencia on 6 August.

The civilian component of government drew on a narrow circle of PSUV figures, including Chávez's former vice-president Elías Jaua (education minister and vice-president of social development) and Chávez's brother Adán (culture minister). The 24 January cabinet changes put pay to hopes that more conciliatory figures would be brought into government. Tareck El Aissami was made vice-president and on 26 January, Maduro extended El Aissami's authority to economic decree power. The appointment met with credulity from the MUD and the US. As interior and justice minister (2008-2012) and as governor of Aragua (2012-2017), El Aissami had presided over an increase in homicides and security sector violence. He had been under investigation in the US since 2011 for alleged money laundering, and since 2015 for alleged involvement in drug trafficking. A further controversy was alleged links with Middle East terrorism networks and claims by CNN en Espanol that El Aissami was at the centre of a ring distributing Venezuelan passports to Middle Eastern nationals through the embassy in Iraq. The Venezuelan telecoms regulatory agency CONATEL rescinded $\mathrm{CNN}$ 's broadcast licence in response.

A further indicator of a hardening of the Maduro presidency was the appointment of Ramón Lobo as finance minister in the January cabinet change. Like El Aissami, Lobo was from the Marxist left of the PSUV and his appointment signalled that no pragmatic shift in policy was to be expected. Lobo had negligible experience of finance, nevertheless Maduro extended his portfolio by fusing the posts of finance minister and economic vice-president. Ahead of Maduro's 2 November admission that Venezuela was incapable of making external debt repayments, Simón Zerpa was appointed finance minister, succeeding Lobo who became president of the Central Bank. Zerpa had held key positions including CFO of PDVSA and president of state financial entities Bandes and Fonden. A key impediment to policy coherence during the Bolivarian Revolution was the constant turnover of ministers. On 11 May, Health Minister Antonieta Caporale 
was dismissed after only four months in the post and following the 9 May release of damning official health data for 2016. The sixteenth health minister in 18 years, and the eighth during Maduro's four years in office, Caporale was replaced by pharmacist Luis López.

In Maduro's sixth cabinet reshuffle on 21 June, ministers were relieved of their posts to stand for the NCA election. Foreign Minister Delcy Rodríguez was replaced by Samuel Moncada, previously Venezuela's ambassador to the UN. Labour Minister Francisco Torrealba was replaced by Néstor Ovalles, who had strong roots in the pro-government trade union movement; Carmen Meléndez was replaced by Major General Carlos Osorio, another controversial appointment owing to claims of corruption during Osorio's tenure as minister of food (2010-13). Major General Juan de Jesús García Toussaintt became transport minister, Admiral Orlando Maneiro was appointed fisheries minister and Major General Luis Motta Domínguez became vice-president for public works. Defence Minister Vladimir Padrino López incorporated the position of vice-president for national security into his portfolio amid pressure on the government to address violent repression of protesters by the state security apparatus. The heads of the army, navy, and the central strategic command were removed after images emerged of live rounds being fired at protesters and of looting by security officials.

\section{CONCLUSION}

Nicolás Maduro and the PSUV survived a perilous year in Venezuela. This was at the cost of the ongoing erosion of Venezuela's much diminished democratic standards, constitutionalism, and economy. Regional and international interventions that were intended to displace the Maduro government, or at least steer it back to a more democratic course, entrenched rather than weakened the PSUV. As had been the case since Hugo Chávez was first elected in 1998, the fractured opposition movement was an explanatory factor in the survival of the Bolivarian Revolution, even as progress toward the Revolution's originals goals of social justice, participation, economic development, and communallevel democracy were reversed. The overt militarization of governance was the most salient trend of 2017, and this opened-up potentially irreconcilable schisms within the Chavista movement and between Venezuelan civil society and the country's security forces. Rectifying Venezuela's searing economic and institutional deterioration fundamentally required dialogue and negotiation between the government and its opponents and the recasting of a new, minimum national consensus. Tragically, political developments in 2017 reflected a paucity of actors, mechanisms or institutions capable of guiding Venezuela's elites toward a process of political reconciliation and national reconstruction. 


\section{BIBLIOGRAPHY}

Álvarez, Ángel E. 2007. “Venezuela 2007: los motores del socialismo se alimentan con petróleo." Revista de Ciencia Política 27 (número especial): 265-289.

Amnesty International. 2008. "Venezuela: Ending Domestic Violence in Venezuela." Retrieved on 13 February 2018 from https://www.amnesty.org/en/documents/ amr53/002/2008/en/

Amnesty International. 2017, 13 January. "Venezuela: Detentions on the Rise Amid WwitchHunt' Against Opposition." Retrieved on 15 February 2018 from https://www.amnesty.org/en/latest/news/2017/01/venezuela-aumentan-detenciones-de-opositores-en-nueva-caceria-de-brujas /

Amnesty International. 2017, 10 May. "Venezuela: Use of Military Courts Against Civilians Undermines Rule of Law." Retrieved on 13 February 2018 from https:/ / www.amnesty.org/en/latest/news/2017/05/venezuela-uso-de-tribunales-militares-contra-civiles-pone-en-jaque-al-estado-de-derecho/

Barbarani, Sofia. 2016, 25 October. "Illegal Abortion is Killing Horrifying Numbers of Women in Venezuela - here's why." The Telegraph. Retrieved on 18 February 2018 from https://www.telegraph.co.uk/women/life/illegal-abortion-is-killing-horrifying-numbers-of-women-in-venez/

Boothroyd Rojas, Rachael. 2016, 12 January. “Venezuelan Supreme Court: 'National Assembly is Void.'" Venezuela Analysis. Retrieved on 10 February 2018 from https:/ /venezuelanalysis.com/news/11813

Buxton, Julia. 2017a. "Social Policy in Venezuela: Bucking Neoliberalism or Unsustainable Clientelism?" In Towards Universal Health Care in Emerging Economies: Opportunities and Challenges, edited by Ilcheong Yi. London: Palgrave, 347-372.

Buxton, Julia. 2017b. 14 March. "Situation Normal in Venezuela: All Fouled Up." NACLA.

Cannon, Barry and Brown, John. 2017. "Venezuela: The Year of Living Dangerously." Revista de Ciencia Política 37 (2): 613-633.

Chun, Zhang. 2017, April 15. “Latin America's Oil-Dependent States Struggle to Repay Chinese Debts." The Diplomat. Retrieved on 15 February 2018 from https:/ / thediplomat. com/2017/04/latin-americas-oil-dependent-states-struggle-to-repay-chinese-debts /

Curacao Chronicle. 2016, 27 December. "Venezuela's PDVSA Mortgages US Refinery Citgo to Russia's Rosneft." Retrieved on 14 February 2018 from http:/ / curacaochronicle.com/ economy/venezuelas-pdvsa-mortgages-us-refinery-citgo-to-russias-rosneft/

Cusack, Asa. 2018. Understanding Alba: The Progress, Problems, and Prospects of Alternative Regionalism in Latin America and the Caribbean. London: ILAS.

Cyr, Jennifer. 2013. "Que veinte años no es nada: Hugo Chávez, las elecciones de 2012 y el continuismo político venezolano." Revista de Ciencia Política 33 (1): 375-391.

Dachevsky, Fernando and Kornblihtt, Juan. 2016, 14 October. "The Reproduction and Crisis of Capitalism in Venezuela Under Chavismo." Latin American Perspectives 44 (1): 78-93.

Di John, Jonathan. 2009. From Windfall to Curse? Oil and Industrialization in Venezuela, 1920 to the Present. University Park: Pennsylvania State University Press.

Dickinson, Elizabeth. 2016, 27 October. "Venezuela's Humanitarian Crisis is worse than you think." Retrieved on 18 February 2018 from https://www.devex.com/news/venezuela-s-humanitarian-crisis-is-worse-than-you-think-88943

Ellsworth, Brian and Chinea, Eyanir. 2017, 2 November. "Venezuela to Restructure Foreign Debt, Default Looms as Possibility." Reuters. Retrieved on 12 February 2018 from https://www.reuters.com/article/us-venezuela-bonds/venezuela-to-restructure-foreign-debt-default-looms-as-possibility-idUSKBN1D230Q

Ellner, Steve and Tinker Salas, Miguel. 2006. Venezuela, Hugo Chávez and the Decline of an Exceptional Democracy. London: Rowan and Littlefield.

Gagne, David. 2017, 16 January. "InSight Crime's 2016 Homicide Round-up." Retrieved on 18 February 2018 from https://www.insightcrime.org/news/analysis/insight-crime-2016-homicide-round-up/ 
Gramer, Robbie. 2017, 12 January. “Venezuela's Meltdown Could be Trump's First Nightmare, Too." Foreign Policy. Retrieved on 18 February 2018 from http://foreignpolicy. com/2017/01/12/venezuelas-meltdown-could-be-trumps-first-nightmare-too/

Gupta, Girish. 2017, 2 August. "Exclusive: Venezuelan Vote Data Casts Doubt on Turnout at Sunday Poll." Reuters. Retrieved on 10 February 2018 from https://www.reuters. $\mathrm{com} /$ article/ us-venezuela-politics-vote-exclusive/exclusive-venezuelan-vote-data-casts-doubt-on-turnout-at-sunday-poll-idUSKBN1AI0AL

Gott, Richard. 2011. Hugo Chávez and the Bolivarian Revolution. London: Verso.

Hanke, Steve. 2018, 25 April. "Venezuela's Hyperinflation and the IMF's Faulty Forecasts." Forbes. Retrieved on 10 February 2018 from https://www.forbes.com/sites/stevehanke/2018/04/25/the-ins-and-outs-of-venezuelas-hyperinflation-spotlights-onthe-imf-and-the-financial-press/\#10f8b369103c

Hausmann, Ricardo. 2018, 2 January. "D Day Venezuela." Retrieved on 12 February 2018 from https://www.project-syndicate.org/commentary/venezuela-catastrophe-military-intervention-by-ricardo-hausmann-2018-01

Hellinger, Daniel. 2016, 2 June. "Oil and the Chavez Legacy." Latin American Perspectives 44 (1): 54-77.

Human Rights Watch. 2017a. 18 April. "Venezuela: Humanitarian Crisis Spilling into Brazil." Retrieved on 12 February 2018 from https:/ / www.hrw.org/news/2017/04/18/venezuela-humanitarian-crisis-spilling-brazil.

Human Rights Watch. 2017b. "Venezuela: Events of 2016." Retrieved on 13 February 2018 from https://www.hrw.org/world-report/2017/country-chapters/venezuela

Immigration and Refugee Board of Canada. 2012, 12 April. "Venezuela: Implementation and Effectiveness of the 2007 Fundamental Law on the Right of Women to Live Free of Violence." Retrieved on 13 February 2018 from http://www.refworld.org/docid/5072901f2.html

Kozarek, Katrina. 2017, 3 October. "Feminists Demand Right to Abortion in Venezuela." Venezuelanalysis. Retrieved on 10 February 2018 from https://venezuelanalysis.com/ video/13409

Ladera, Marynes. 2017, 30 April. "Relanzarán el banco de la mujer." Retrieved on 10 February 2018 from http:/ / minci.gob.ve/2017/04/relanzaran-banco-la-mujer/

Latouche, Miguel. A. 2016, 25 November. "Political Dialogue Is a Lost Art in Venezuela and the Vatican's Intervention Won't Help." The Conversation. Retrieved on 13 February 2018 from https://theconversation.com/political-dialogue-is-a-lost-art-in-venezuela-and-the-vaticans-intervention-wont-help-68906

Lawler, Alex, El Gamal, Rania and Nasralla, Shadia. 2017, 30 November. "OPEC, Russia Agree Oil Cut Extension to End of 2018." Reuters. Retrieved on 11 February 2018 from https:/ / www.reuters.com/article/us-opec-meeting/opec-russia-agree-oil-cut-extension-to-end-of-2018-idUSKBN1DU0WW

López Maya, Margarita and Lander, Luis. 2010. “Venezuela (2009): En medio de dificultades avanza el modelo socialista del Presidente Chávez." Revista de Ciencia Política 30 (2): 537-553.

Maignon, Thais and Welsch, Friedrich. 2009. "Venezuela (2008): hoja de ruta hacia el socialismo autoritario." Revista de Ciencia Política 29 (2): 633-656.

Mallett Outtrim, Ryan and Lucas Koerner. 2017, 11 December. "Venezuela's Socialists Score Landslide Win in Mayoral Election." Venezuelanalysis. Retrieved on 13 February 2018 from https://venezuelanalysis.com/news/13543

Martin, Jorge. 2018. "Venezuela: Economic Crisis Worsens - Which Way Forward?" In Defence of Marxism. Retrieved on 15 February 2018 from https://www.marxist.com/venezuela-economic-crisis-worsens-which-way-forward.htm

McCoy, Jennifer and Myers, David. 2006. The Unravelling of Representative Democracy in Venezuela. Baltimore: Johns Hopkins University Press.

Merco Press. 2017, 29 December. “Venezuelan Observatory of Violence Published Its Annual Report." Retrieved on 10 February 2018 from http:/ / en.mercopress.com/2017/12/29/ venezuelan-observatory-of-violence-published-its-annual-report 
Minesterios de Relaciones Exteriores. 2017, 8 August. "Declaración de Lima." Retrieved on February 152018 from http://www.rree.gob.pe/SitePages/declaracion_conjunta.aspx?id=DC-007-17

Monaldi, Francisco. 2015. "Impact of the Decline in Oil Prices on the Economics, Politics and Oil Industry of Venezuela." Retrieved on 12 February 2018 from http:/ / energypolicy. columbia.edu/sites/default/files/energy/Impactper cent20ofper cent20theper cent20Declineper cent20inper cent20Oilper cent20Pricesper cent20onper cent20Venezuela_Septemberper cent202015.pdf

Monaldi, Francisco. 2018, 24 January. "The Death Spiral of Venezuela's Oil Sector and What Can Be Done About It." Forbes. Retrieved on 13 February 2018 from https:/ /www. forbes.com/sites/thebakersinstitute/2018/01/24/the-death-spiral-of-venezuelas-oilsector-what-if-anything-can-be-done-about-it/\#a44ea967e606

Ramsey, Geoff. 2017a, 8 December. "What EU Sanctions Mean for Venezuela." WOLA. Retrieved on 18 February 2018 from https://www.wola.org/analysis/what-european-union-sanctions-mean-for-venezuela /

Ramsey, Geoff. 2017b, 14 December. “Venezuelan Government, Opposition Meet for 2nd Round of Dominican Republic Negotiations." WOLA. Retrieved on 13 February 2018 from https://venezuelablog.org/venezuelan-government-opposition-meet-2nd-round-dominican-republic-negotiations/

Reuters. 2018, 8 January. "Venezuela 2017 Annual Inflation at 2,616 Percent: Opposition Lawmakers." Retrieved on 10 February 2018 from https://www.reuters.com/article/us-venezuela-economy-inflation/venezuela-2017-annual-inflation-at-2616-percent-opposition-lawmakers-idUSKBN1EX23B

Reuters. 2018, 15 March. "Venezuela Gold Reserve Falls 14 pct in 2017." Retrieved on 11 February 2018 from https:/ / www.reuters.com/article/venezuela-economy-gold/venezuela-gold-reserve-value-falls-14-pct-in-2017-idUSL1N1QX1FD

Rodriguez, Francisco. 2018, 12 January. “Why More Sanctions Won't Help Venezuela." Foreign Policy. Retrieved on 10 February 2018 from http://foreignpolicy.com/2018/01/12/ why-more-sanctions-wont-help-venezuela/

Sagarzazu, Iñaki 2014. "Venezuela (2013): un país a dos mitades." Revista de Ciencia Política 34 (1): 315-328

Sánchez Urribarrí, Raúl A. 2016. “Venezuela (2015): Un régimen híbrido en crisis.” Revista de Ciencia Política 36 (1): 365-381.

Small Arms Survey. 2017. “New Report: More Than One Million Lives Could Be Saved by 2030." Retrieved on 19 February 2018 from http:/ / www.smallarmssurvey.org/aboutus/highlights/2017/highlight-gvd-report.html

Smilde, David. 2016, 5 August. "With Blacklisted Officials, Venezuela's Maduro Builds a Core." WOLA Blog. Retrieved on 19 February 2018 from http:/ /venezuelablog.tumblr.com/ post/148494196139/with-blacklisted-officials -venezuelas- Maduro

Smilde, David. 2017, March 2. "Venezuela: Options for U.S. Policy." Testimony before the United States Senate Committee on Foreign Relation. Retrieved on 10 May 2018 from https://www.foreign.senate.gov/imo/media/doc/030217_Smilde_Testimony.pdf

Spanakos, Anthony and Pantoulas, Dimitri. 2017. "The Contribution of Hugo Chávez to an Understanding of Post-Neoliberalism." Latin American Perspectives 44 (1): 37-53.

The New York Times. 2017, 12 August. "Trump Alarms Venezuela With Talk of a 'Military Option.'" Retrieved on 19 February 2018 from https:/ /www.nytimes.com/2017/08/12/ world/americas/trump-venezuela-military.html

The White House Press Secretary. 2015, 9 March. "Fact Sheet: Venezuela Executive Order." Retrieved on 13 April 2018 from https://obamawhitehouse.archives.gov/the-pressoffice/2015/03/09/ fact-sheet-venezuela-executive-order

Tinker Salas, Miguel. 2009. The Enduring Legacy: Oil, Culture, and Society in Venezuela. Durham: Duke University Press.

Ulmer, Alexandra. 2017, 31 December. "Venezuela's Maduro is Destructive King Herod, Warns Ex-Oil Czar." Reuters. Retrieved on 14 February 2018 from https://uk.reuters.com/ 
article/uk-venezuela-politics/venezuelas-maduro-is-destructive-king-herod-warns-ex-oil-czar-idUKKBN1EP0FA

UNICEF. 2017, 12 May. "Statement Attributable to UNICEF's Regional Office for Latin America and the Caribbean on Health Data in Venezuela." Retrieved on 10 March 2018 from https://www.unicef.org/media/media_95962.html

U.S. Department of the Treasury. 2017, 13 February. "Treasury Sanctions Prominent Venezuelan Drug Trafficker Tareck El Aissami and his Primary Frontman Samark Lopez Bello." Retrieved on 11 March 2018 from https://www.treasury.gov/press-center/press-releases/Pages/as0005.aspx

United States Southern Command. 2017, 6 April. "Posture Statement of Admiral Kurt. W. Tidd, Commander, United States Southern Command Before the $115^{\text {th }}$ Congress Senate Armed Service Committee." Retrieved on 11 March 2018 from http:/ / www.southcom. mil/Portals/7/Documents/Postureper cent20Statements/SOUTHCOM_2017_posture_statement_FINAL.pdf?ver=2017-04-06-105819-923 p.8

Valero Jorge. 2010, 21 September. "Statement by Ambassador Jorge Valero. High Level Plenary meeting on the UN Millennium Development Goals." New York: UN. Retrieved on 12 February 2018 from http://www.un.org/en/mdg/summit2010/debate/VE_en.pdf

Velasco, Alejandro. 2018, February. “The Pyrrhic Victories of Venezuela's President." Current History. Retrieved on 9 May 2018 from http://www.currenthistory.com/Velasco_ CH_Feb_issue_free_article.pdf

Weisbrot, Mark. 2016. “Venezuela: Dismantling a Weapon of Mass Destruction.” Triple Crisis. Retrieved on 10 May 2018 from http:/ / triplecrisis.com/venezuela-dismantling-a-weapon-of-mass-destruction/

Woody, Christopher. 2017, 14 July. "Venezuela is at Risk of Losing an Entire Generation." Business Insider UK. Retrieved on 10 February 2018 from http://uk.businessinsider.com/venezuela-protest-driving-migration-changing-demographics-and-politics-2017-7? $\mathrm{r}=\mathrm{US} \& \mathrm{IR}=\mathrm{T}$

Zuñiga, Mariana. 2018, 6 February. "American Court Opens Historic Hearing into Venezuela Rape and Torture Case." The Guardian. Retrieved on 14 February 2018 from https://www.theguardian.com/global-development/2018/feb/06/us-human-rights-court-landmark-hearing-venezuela-rape-torture-case-linda-loaiza

Julia Buxton is Professor of Comparative Politics in the School of Public Policy at Central European University, Budapest Hungary and Senior Researcher at the Global Drugs Policy Observatory at the University of Swansea. A specialist on Latin America, her more recent publications on Venezuela include: 'Defusing Venezuela' in Seton Hall Journal of Diplomacy and International Relations, XIX (1), 2018; 'Situation Normal in Venezuela: All Fouled Up' NACLA Report on the Americas 49(1) 2017; 'Social Policy in Venezuela: Bucking Neoliberalism or Unsustainable Clientelism?' in I. Yi (ed.) Towards Universal Health Care in Emerging Economies: Opportunities and Challenges (2017, Palgrave); 'Swimming Against the Tide: Venezuela and Peace Operations', in K. Kenkel, South American Peace Ops, (2013, Routledge); and 'Forward into History: Understanding Barack Obama's Latin America Policy' Special Edition of Latin American Perspectives, 2011. Emai: BuxtonJ@spp.ceu.edu 